\title{
Orthodox Christianity and the State: the Relevance of Globalization
}

\author{
VICTOR ROUDOMETOF
}

Orthodox Christianity remains relatively understudied and its scholarly analysis still suffers from widespread misconceptions. This article's opening section is devoted to de-bunking of past biases, as these emerge in conventional or traditional modernist images of Orthodoxy in scholarship. Next, the article lays out a global perspective and argues that such a perspective can contribute greatly toward a different understanding of the relationship between Orthodox Church and politics. It proposes a series of distinct church-state patterns as observed in Orthodox pre-modern and modern societies. The variety of these arrangements strongly suggests the need to overturn past interpretations and to accept the basic premise that Orthodox Christianity has a multifaceted relationship to society and culture - as well as to accept the notion that, from within the lenses of historical globalization, Orthodoxy has experienced historical change and that its current version is in fact not the relic of an unchanged tradition but rather the product of social change and of adjustment to globalization.

Keywords: globalization, Orthodox Christianity, state, nation, culture

\section{The Limits of Traditional Perspectives and the Relevance of Globa- lization}

Traditional scholarly discourse in the social sciences frequently assumes that Orthodox Christianity is predicated upon a close-knit relationship between religion and politics and a systematic intertwining between Church and State, which often make Orthodox countries anti-secular and hostile to democracy and civil society. Orthodox Christianity's participation within European history has been cast aside in large part due to the images that prevailed over the role and status of Byzantium. "Byzantium" per se does not actually exist. It was Hieronymus Wolf (1516-1580) who first introduced this word into scholarship. ${ }^{2}$ Later on, $19^{\text {th }}$ century British historians contrib-

\footnotetext{
${ }^{*}$ Victor Roudometof, Department of Social and Political Sciences, University of Cyprus. Address: Department of Social and Political Sciences, University of Cyprus, PO Box 20537, Nicosia 1678, Cyprus, e-mail: roudomet@ucy.ac.cy

1 Johann P. Arnason, "Approaching Byzantium: Identity, Predicament, and Afterlife", in: Thesis Eleven 62 (2000), p. 59-69; Judith Herrin, Byzantium: the surprising life of a medieval empire, Princeton, NJ, Princeton University Press 2007.

2 Alexander Kazhdan, "Byzantium", in: Alexander P. Kazhdan (ed.), The Oxford Dictionary of Byzantium, Oxford, Oxford University Press 1991.
} 
uted heavily to the wide proliferation of this word's negative connotation among the English-language public. ${ }^{3}$ To mention one prominent example, ${ }^{4}$ comparative analysis between "Occident" and "Orient" builds directly upon the historical scholarship prevalent at his time and hence reaches highly unreliable conclusions with regard to the Orthodox part of Europe.

During the Cold War era, these predispositions were used to justify the imposition of communism in the Orthodox part of Europe. After the fall of communism, influential commentators ${ }^{5}$ suggested a link between the cultural traditions of Eastern Europe and the failure of some of these countries to accomplish a successful transition to democracy or to successfully integrate into the new post-1989 Europe. This cultural tradition, we are told, has often endorsed ethno-nationalism and fundamentalist protectionism. "Whatever changes may impact the world," Ramet ${ }^{6}$ writes, "the Orthodox Church refuses, for the most part, to accommodate itself to change, standing fixed in time, its bishops' gaze riveted on an 'idyllic past' which serves as their beacon." The strong link of Orthodoxy with local national identities is frequently used in support of this thinking. "The Orthodox Churches" Ramet and Pavlakovic ${ }^{7}$ write, "like the ancient religions, are the Churches of their respective nations, their myths being the myths of their respective nations."

Relevant social scientific fields, such as the mostly-Western based Sociology of Religion, typically rely heavily on theoretical paradigms selectively derived from and applied upon a small and selective group of Western nations. ${ }^{8}$ This parochialism is connected to the prevalence of secularization as the field's central theoretical focus. The secularization paradigm is in turn derived from the broader modernization paradigm that has been the target of numerous criticisms since the1960s. One of its major shortcomings is its extensive reliance upon the image of the 'isolated individual' and

\footnotetext{
3 Timothy E. Gregory, A History of Byzantium, Oxford, Basil Blackwell 2005, p. 3.

4 Max Weber, Economy and Society (2 vols.), Berkeley, CA, University of California Press 1922 [1968].

5 Robert D. Kaplan, Balkan Ghosts: A Journey Through History, New York, St. Martin's Press 1993; George Kennan, The Other Balkan Wars: A 1913 Carnegie Endowment Inquiry in Retrospect, Washington DC, Carnegie Endowment for International Peace 1993; Samuel P. Huntington, The Clash of Civilizations and the Remaking of the World Order, New York, Simon \& Schuster 1996.

6 Sabrina P. Ramet, "The Way We Were - And Should Be Again? European Orthodox Churches and the 'Idyllic Past"', in: T. Byrnes \& P. Katzenstein (eds.), Religion in an Expanding Europe, Cambridge, Cambridge University Press 2006, p. 148-175, here p. 148.

7 S. P. Ramet, Vjeran Pavlakovic, Serbia Since 1989, Seattle, WA, University of Seattle Press 2005, p. 255.

8 Martin Riesebodt, May Ellen Konieczny, “Sociology of Religion”, in: John R. Hinnells (ed.), The Routledge Companion to the Study of Religion, London, Routledge 2010, p. 145-64, 159-60.
} 
its use of culture as a residual category invoked only as a defense against secularism. ${ }^{9}$ Such a perspective fails to incorporate the cultural dimension of religion and offers instead a theoretical model that naturalizes Western cultural specificity. When considering Orthodox Christianity, this model's limits become apparent. ${ }^{10}$ Using globalization offers the opportunity to address this vexing issue by developing an approach sensitive to cultural specificity.

That is particularly true when it comes to the historical intertwining between religion and globalization. The historical dimension of globalization contains important challenges to conventional modernist perspectives. Instead of interpretations that view globalization as a historically recent phenomenon, a long-term view of globalization necessarily entails de-centering the conventional narrative of Western modernization. ${ }^{11}$ From such a perspective, pre-modern globalization was important and consequential for humanity. ${ }^{12}$ This historically sensitive orientation encompasses the construction and proliferation of world religions. ${ }^{13}$ When globalization provides the overall conceptual framework, then there is no single narrative of modernization that is universally applicable. ${ }^{14}$ In contrast to conventional narratives that are based on the theorization of the Western experience alone, a global-historical perspective enables the inclusion of different historical cases without framing their historical trajectories in terms of convergence or divergence from Western modernity. Thus, from such a perspective the rise of the West and the emergence of Western modernity itself occur within a far more encompassing world-historical globalization.

In this sense the use of globalization offers the possibility to transcend the Western self-image implicit in conventional narratives of modernity. Globalization does not simply destroy local life worlds and tra-

\footnotetext{
9 Victor Roudometof, “The Glocalisations of Eastern Orthodox Christianity”, in: European Journal of Social Theory 16 (2/2013), p. 226-245.

10 Peter McMylon, Maria Vorozhishcheva, "Sociology and Eastern Orthodoxy", in: Ken Perry (ed.), The Blackwell Companion to Eastern Christianity, Oxford, Blackwell 2007, p. 462-479.

11 Patrick K. O'Brien, “Historiographical Traditions and Modern Imperatives for the Restoration of Global History", in: Journal of Global History 1 (1/2006), p. 3-39.

12 John M. Hobson, The Eastern Origins of Western Civilization, Cambridge, Cambridge University Press 2004; Peter Stearns, Globalization in World History, London, Routledge 2009; Eric Wolff, Europe and the People Without History Berkeley, CA, University of California Press 1982.

13 Lester Ray Kurtz, Gods in the Global Village: The World's Religions in Sociological Perspective, London, Sage 1996.

14 On the difference between this perspective and the multiple modernities agenda, see: V. Roudometof, "Globalization, Space and Modernity", in: The European Legacy 8 (1/2003), p. 37-60.
} 
ditional local structures and settings - but rather interacts with them in a local-global nexus that is more accurately referred to as 'glocalization'. ${ }^{15}$ That is, old forms of territorial attachments are decoupled and new forms of such attachments are forged. This dialectic is prominently displayed in trends toward greater ecumenical orientation as well as in transnational religion. The spread of various "world religions" 16 involves their simultaneous localization: they are reconstituted in new locales and reconstruct communal attachments in new forms. This might lead both toward forging global forms of religiosity or an ecumenical orientation that decouples particularistic attachments in favor of a global religious community or to the construction of new branches of a religion or religious varieties. As religions are thus reconfigured, new formations emerge in historical time. These formations are cultural hybrids that blend religious universalism with several forms of local, national or ethnic particularisms. Through these processes, the conventional association of religion with a geographical region is destabilized. Beyer ${ }^{17}$ suggests that globalization involves multiple glocalizations. These are not mechanically connected to historical periods but occur both across historical eras and synchronically, subject to the specific cultural and political conditions of a given milieu. In my work ${ }^{18}$ I have extended this model of multiple glocalizations by presenting four variants of glocalization as historically concrete examples that involve a fusion between religious universalism and local particularism. These are vernacularization, indigenization, nationalization and transnationalization. Each represents a specific form of blending universal religion along particular human configurations (e.g., empire, ethnicity, nation-state and transnational migration). But they are not distinct simply because of their historical specificity; they are distinct because each of them offers a discrete analytical ordering or combination of the global and the local. In other words, each of them offers a different means for negotiating and ordering the global/local blend into cultural stable and concrete formats.

15 V. Roudometof, "The Glocalisations of Eastern Orthodox Christianity”, p. 226-245; idem, Globalization and Orthodox Christianity: The Transformations of a Religious Tradition, London, Routledge 2014.

16 Luke M. Herrington, "Globalization and religion in historical perspective: A paradoxical relationship", in: Religions 4 (1/2013), p. 145-165, http://www.mdpi.com/20771444/4/1/145, viewed on March 9, 2018.

17 Peter Beyer, "Globalization and Glocalization", in: James A. Beckford, N.J. Demerath III (eds.), The Sage Handbook of the Sociology of Religion, Sage Publications 2007, p. $98-117$.

18 V. Roudometof, “The Glocalisations of Eastern Orthodox Christianity”, p. 226-245; idem, Globalization and Orthodox Christianity. 


\section{Globalization in History: the View from the East}

For current purposes, let me address here in concrete historical terms how historical globalization can be used in order to explain the division of Chalcedonian Christianity into Orthodox and Catholic branches. The following help shed light into the developments that took place within the eastern part of Europe in comparison to the historical developments in the western part of the continent. But unlike modernist accounts, these historical events are placed here in a comparative canvas, whereby the interactions between the eastern and the western part of Europe are seen as constitutive of the formation of distinct religious branches.

Globalization's pace and influence for the crystallization of various branches of Christianity requires a bird's-eye view of historical developments. In fact, the conventional narrative of the social sciences is a narrative that naturalizes the modernization of Western societies. To understand the multiple entanglements between the various streams of Eastern Christianity and globalization requires taking into account the realization that globalization does not necessarily involve a mystical long-term trend toward universalization but includes processes of fragmentation or hybridization. Historically, the creation of distinct branches of Christianity - such as Orthodox and Catholic Christianity - bears the mark of this particularization of religious universalism. This blend of religious universalism and particularism is therefore a matter of concrete empirical reality, of the historical record itself.

For our purposes, an important point of departure is the Council of Chalcedon (451 AD). To address a variety of Christological disputes, the council introduced the formula of Christ having two natures united yet completely distinct - and in the council's aftermath, its followers began employing the term "Orthodox" (= having the "right" or correct faith). For several centuries, Chalcedonian Christianity was the form of Christianity aligned with the Roman Empire; its adherents were "Orthodox" Christians and branded nonChalcedonians as "heretics" or "heterodox". The above took place within the context of Christianity's readjustment as the Roman Empire's official religion. That involved the reconfiguration of the relationship between Church and State, whereby the principle of complementarity or symphonia provided the basic principle of governing the relationship between public authority and religious hierarchy. The high clergy provided spiritual leadership and exercised moral control upon state authority; whereas the Emperor was expected to play a role in protecting, expanding and serving Christianity. Complementarity has been misconstrued as cesaropapism, or the secular ruler's undue intervention into the affairs of the Church. ${ }^{19}$ This interpretation is predicated

19 M. Weber, Economy and Society. 
upon the Western division of a "secular" from a "religious" sphere. ${ }^{20}$ Only from within these lenses is it possible to deem that a political leader's actions violate the separation of the realms. But for the Christian Roman Empire the understanding of the relationship between the religious order and the state was vastly different. The emperors were the guardians of the faith, and consequently they were empowered to intervene in religious affairs. For centuries, the Roman Empire was a paradigmatic case of this mutual agreement between Christianity and the State, ${ }^{21}$ predicated upon an understanding of the common origins of both Church and State as God's gift to humankind; a vision that implied that Church and State ought to function harmoniously to better society. As Makrides ${ }^{22}$ remarks, symphonia belongs to the past and it is inaccurate to uncritically apply it in contemporary contexts.

While the eastern Roman Empire thwarted foreign invaders and survived until 1204, in the empire's western part, the State collapsed in 476. Hence, Rome's pope appropriated the formerly imperial title of pontifex maximus and articulated the notion of a divinely sanctioned "apostolic see." Although in the West only the pope could successfully claim such an apostolic see, in the East there were dozens of cities who could lay a similar claim. ${ }^{23}$ As a result, the notion of an apostolic see never developed in the East. Moreover, unlike the pope, the patriarchs of the East had to contend with a powerful political authority that played a key role in ecclesiastical affairs. The original symphonia between the Roman emperor and Christianity's high clergy involved a conception of ecclesiastical governance by the so-called pentarchy - the participation of the five original or ancient patriarchates of Rome, Antioch, Alexandria, Jerusalem and Constantinople. To be acceptable, ecumenical church councils required the participation of these patriarchs or their representatives. From within the imperial point of view, which subsequently also became the Orthodox viewpoint, the bishop of Rome was primus inter pares (first amongst equals).

Up until the $8^{\text {th }}$ century, imperial control was still effective in Italy and the Papacy remained under the influence of Eastern ecclesiastical personnel (monks, bishops, pilgrims). ${ }^{24}$ The collapse of imperial authority on Italian

20 Talal Asad, Genealogies of Religion: Discipline and Reasons of Power in Christianity and Islam, Baltimore, MD, Johns Hopkins University Press 1993.

21 Cyril Mango, Byzantium: The Empire of New Rome, New York, Scribner 1980.

22 Vasilios N. Makrides, "Why Are Orthodox Churches Particularly Prone to Nationalization and Even to Nationalism?", in: St Vladimir's Theological Quarterly 57 (3-4/2013), p. $325-352,331$.

23 John Meyendorff, The Byzantine Legacy in the Orthodox Church, (Greek ed.), Athens, Armos 1990 p. 103, 274, 305.

24 Michael McCormick, "Western Approaches (700-900)", in: Jonathan Shepard (ed.), The Cambridge History of the Byzantine Empire, c. 500-1492, Cambridge, Cambridge University Press 2009, p. 395-432, 410-412. 
soil led the Papacy to realign itself with Frankish rulers and culminated to Charlemagne's crowing in 800 as Roman emperor. ${ }^{25}$ This reorientation entailed a shift in attitude toward the East. The ancient Roman heritage was seen as safeguarded by Roman Catholicism in the West. Westerners referred to the Holy German emperors as Emperors of the "Romans," whereas the Eastern Roman emperors were called Emperors of the "Greeks" (= Orthodox). It was within the broader context of this political realignment that the papal court concocted the so-called Donation of Constantine - a powerful forgery, according to which Emperor Constantine I, prior to becoming a Christian, surrendered his authority to Pope Sylvester I (314-335), who returned it while retaining preeminence over the other patriarchs. ${ }^{26}$ This forgery formed one of the bases of later papal claims and was considered authentic until the 15th century.

Overall, the East's complementary relationship between church and emperor stood in sharp contrast to the Roman Catholic Church's policy, especially after the 10th century Gregorian reform effort. The crystallization of the "papal monarchy" ${ }^{27}$ entailed the standardization of numerous religious practices, but it also involved the initiation of and involvement in the Crusades as well as the attempt to remove secular control over religious estates, which caused the famous Investiture Controversy. While the Great Schism of 1054 is conventionally seen as signaling the rift between the two branches of Christianity, it is worth pointing out that this is not entirely accurate. ${ }^{28}$ Rather, it was the support offered by the Papacy to the Crusades and most pointedly the $4^{\text {th }}$ Crusade, which ended up conquering Constantinople in 1204. The Crusaders sacked the city, looted its wealth and shipped it to Western Europe, and called upon Orthodox bishops to submit to Papal authority.

Only after the disappearance of imperial rule did Orthodox institutions begin to operate autonomously and without relying upon political leadership. Between the two falls of Constantinople (1204-1453) both doctrinal and liturgical evolution took place, contributing heavily to the crystallization of Orthodox Christianity in the format that is commonly known and practiced in the world today. ${ }^{29}$ The two abortive acts of union with

\footnotetext{
25 J. Herrin, The Formation of Christendom, Oxford, Basil Blackwell 1987, p. 379-460; Henry Chadwick, East and West: The Making of a Rift in the Church From Apostolic Times Until the Council of Florence, Oxford, Oxford University Press 2003, p. 84-87.

26 Diarmaid MacCulloch, A History of Christianity: The First Three Thousand Years, London, Penguin 2009, p. 351.

27 Collin Morris, The Papal Monarchy: The Western Church from 1050 to 1250, Oxford, Clarendon Press 2001.

28 V. Roudometof, Globalization and Orthodox Christianity, p. 23.

29. Ibidem, p. 50-57.
} 
Rome (1274 and 1438-1439) were instrumental in fostering Orthodox defiance to Catholic objectives of administrative union under the auspices of papal authority. The subsequent sense of an existential gap vis-à-vis "Western" Christianity has had long-lasting consequences. After the Enlightenment era, western European modernization raised the issue of confronting the challenges of modernity not only within its own cultural milieu but also within the milieu of eastern and southeastern Europe. Orthodox theological discourse has voiced a critique of Western modernity, founded upon the limits of rationality as a means for providing the world with meaning. ${ }^{30}$ Long before Max Weber referred to the "iron cage" of modernity to point out the limitations of modern rationality to offer meaningful ends to individuals, Orthodox theological discourse has employed a very similar leitmotif. ${ }^{31}$ Orthodox theology has articulated a vision of apophatic theology as a discursive means for deciding matters of faith. ${ }^{32}$ Without going into details, apophaticism has been a strategy - used in the era of the Church's ecumenical councils - which aimed at stating what God is not, as opposed to what God is. God is incomprehensible for humans and human words cannot describe what God is; hence, authoritative proclamations state more accurately what God is not. It is easy to see how anti-rationalism and anti-modernism often degenerate into sheer anti-Westernism, the charge typically levied against Orthodox Christianity. To the extent that the critique of Western Reason is a negation of modernity, that is certainly correct. But philosophical or theological critique is not identical to the critique of modernization; historically, all over the world, secular and sometimes even ecclesiastical leadership has taken the initiative for local societies to "catch up" with the "modern West." One has to carefully distinguish between the philosophical and the policyoriented critique of modernity and modernization.

Up until 1204 Orthodox Christianity was the faith of the universal Christian empire. In the $13^{\text {th }}$ century both Serb and Bulgarian political leaders succeeded in gaining legitimacy from the feeble Roman authority and also employed the creation of autocephalous sees as a means for bolstering their political authority. ${ }^{33}$ In such visions, political rulers used the imperial hierarchical order to further their own legitimacy. In doing so, they ac-

30 Daniel B. Clendenin, Eastern Orthodox Christianity: A Western Perspective, Grand Rapids, MI, Baker Books 2002, p. 48-64.

31 V. N. Makrides, "Orthodox Christianity, Rationalization, Modernization: An Assessment", in: V. Roudometof, A. Agadjanian, J. Pankhurst (eds.), Eastern Orthodoxy in a Global Age: Tradition Meets the 21st Century, Walnut Greek, CA, Alta Mira Press 2005, p. 179-209. 32 Nicos Mouzelis, "Self and Self-Other Reflexivity: The Apophatic Dimension", in: European Journal of Social Theory 13 (2/2010), p. 271-284.

33 V. N. Makrides, "Why Are Orthodox Churches", p. 325-352. 
cepted the hierarchy's legitimacy and the emperor's superior place within it, while at the same time they adopted titles, rituals, ceremonies, practices and rules for their purposes. For Russian or Bulgarian tsars, their capital cities of Moscow and Veliko Turnovo were a "new Rome" or new Tsargrad (the emperor's city, i.e., Constantinople). ${ }^{34}$ The notion of a post-Byzantine or Orthodox commonwealth, ${ }^{35}$ or a religioscape ${ }^{36}$ offers the conceptual means to capture the specifics of this religious milieu. This commonwealth entailed both horizontal and vertical links. The horizontal links involved pilgrimages, travels to monasteries, translations of ecclesiastical texts and rituals as well as numerous other religious activities. Regional commercial links were used as a means of fostering cross-regional communication. In spite of the decline and eventual collapse of imperial authority, the community of faith and of spiritual role models gained in strength. The vertical links entailed recognition of Orthodoxy's hierarchical order that involved a series of political units of roughly equivalent status united under the umbrella of Orthodoxy, in which the Ecumenical Patriarch of Constantinople became a dominant figure.

\section{Early Modern and Modern Globalization in the Orthodox part of Europe}

Over the post-1453 period the majority of Orthodox Christians lived in the Ottoman and Russian empires. Church-State relations within these two empires evolved differently. Their differences formed the basis for large historical divergences observed in these two regions in the modern era. While in the Russian Empire popular indigenization of religious practices was initially endorsed by local authorities and later on reversed by a rising Empire eager to bolster its international credentials as guardian of all the Orthodox, in the Ottoman Empire the post-1453 era was characterized by a revival of the earlier Roman model - albeit a symphonia reached with a non-Orthodox sovereign (e.g. the Ottoman Sultan). Let me sketch the historical developments in a somewhat crude summary form.

In 1448 the Grand Prince of Moscow took the initiative to form a separate autocephalous religious hierarchy through the arrangement of the un-canonical election of a Russian archbishop by an assembly of local bishops. That effectively broke off its past dependence upon the Ecumenical Patriarchate. After the 1453 second fall of Constantinople the Grand Duchy

34 Jonathan Shepard, "The Byzantine Commonwealth, 1000-1500", in: Michael Angold (ed.), The Cambridge History of Christianity. Vol. 5: Eastern Christianity, Cambridge, Cambridge University Press 2006, p. 3-52, here p. 19.

35 Paschalis M. Kitromilides, An Orthodox Commonwealth: symbolic legacies and cultural encounters in southeastern Europe, Aldershot, Ashgate Variorum 2007.

36 V. Roudometof, Globalization and Orthodox Christianity. 
of Moscow was the only surviving independent Orthodox State. For the Russians, the 1453 fall of Constantinople to the Ottomans was divine punishment for the 1439 aborted union with Rome. ${ }^{37}$ Popular tales proclaimed that Moscow was the ultimate depository of the Orthodox faith. Therein lay the origins of the popular, yet deeply misunderstood, myth of Moscow as a Third Rome. The transformation of Moscow's Duchy into the Russian Empire was solidified in the 16th century, under Ivan IV (1547-1584). His rule mirrored a new modus vivendi between State and ecclesiastical authority. Moscow was a New Jerusalem, a land of chosen people: In 1547, at the heart of Ivan IV's coronation, the tsar was "declared to be the heir of David and Muscovy to be God's new Chosen People". ${ }^{38}$ This conception combined the popular perception that the Russians were the only ones preserving the correct faith with the notion of a divinely ordained monarchy ${ }^{39}$. Taking advantage of the Ecumenical Patriarchate's weakened state the Russian Court used the 1589 visit of Ecumenical Patriarch Jeremiah II to extract a patriarchal decision (later on approved by an Orthodox council) that elevated the Moscow prelate to the status of a patriarch.

The $17^{\text {th }}$ century consolidation of Russian monarchy, though, had important repercussions that shaped the historical trajectory of Russian Orthodoxy. As the court and the emperor became powerful international actors, the misalignment between Russian ecclesiastical practices and those in the rest of the Orthodox commonwealth became a source of worry for ecclesiastical reformers and political leaders. At the 1666-1667 Moscow councils an attempt was made to realign indigenous religious practices with those prevalent in the rest of the Orthodox religioscape. In order to crush dissent, the opposition was excommunicated. But for dissenters, "the adoption of the Greek [liturgical] models was . . . a condemnation of Russian past - a rejection, rather than an affirmation of the Moscow - Third Rome ideology". ${ }^{40}$ Monastic recalcitrance, the unwillingness and inability of the parish priests to accept the reforms and the eventual emergence of a new generation of dissenters, contributed to the consolidation of the schism. The schism placed popular or demotic understandings of Russianness (russkij)

37 Stella Rock, "Russian Piety and Orthodox Culture, 1380-1589", in: M. Angold (ed.), The Cambridge History of Christianity. Vol. 5: Eastern Christianity, Cambridge, Cambridge University Press 2006, p. 253-275, here p. 272.

38 Daniel Rowland, "Moscow: The Third Rome or the New Israel?", in: The Russian Review 55 (4/1996), p. 591-614, here p. 597.

39 Nikolas Gvosdev, An Examination of Church-State Relations in the Byzantine and Russian Empires with an Emphasis on Ideology and Models of Interaction, Lewiston, NY, Edwin Mellen 2001.

40 Paul Meyendorff, Russia, Ritual and Reform: The Liturgical Reforms of Nikon in the 17th Century, Crestwood, NY, St. Vladimir's Seminary Press 1991, p. 223. 
against the imperial project (rosiiskii). The chasm persisted for the coming centuries, and the project of empire-making meant the two were impossible to reconcile ${ }^{41}$. Blending elements of social protest against imperial autocracy, Orthodox millenarianism and an autochthonous-based sentiment, the dissenters formed the groups that by the 18th century came to be known as Old Believers. By late 19th century, it is estimated that perhaps even $40 \%$ of the peasantry were Old Believers. ${ }^{42}$

In the Ottoman Empire, the Ecumenical Patriarchate revived its previous model but had to readjust it to the reality of submission to the Ottoman Sultan. In order to justify submission to a non-Christian overlord, myths and legends postponed the overthrow of Muslim rule to the End of Time. The popular religious millenarianism of the Ottoman era registers a cultural accommodation to the new realities: The Christian Empire collapsed as God's punishment for the sins of the Christians, and it was said that it would reconstitute itself as part of the Second Coming or some other future mythological event ${ }^{43}$. The folk tales that proliferated after 1453 offered a plausible account for this reality. Orthodox institutions fostered acceptance of the status quo and religious unity among the Orthodox. ${ }^{44}$ The Church's orientation became more ecumenical and that curtailed the previous trend toward the establishment of separate religious authorities. ${ }^{45}$ To explain this, it is necessary to take into account the Orthodox Christians' status within the Ottoman world empire. Although non-Muslims were formally excluded from authority positions, they were not reduced to mere subjects. In accordance to Islamic custom and raison d'etat, Ottoman rulers organized the non-Muslims under their respective religious leaders. Jews, Catholics and Orthodox Christians became incorporated into the empire within their own confessional associations (millets). ${ }^{46}$ The formerly political identity of the Roman subjects became, under Ottoman rule, confined to the Rum millet. Its members called themselves "Christians" or kept using their earlier "Roman" (Rum) name. Western Europeans referred to them as "Greeks" (Greek-

\footnotetext{
41 Geoffrey Hosking, "Can Russia Become a Nation-State?”, in: Nations and Nationalism 4 (4/1998), p. 449-462.

42 Paul A. Bushkovitch, Religion and Society in Russia: The Sixteenth and Seventeenth Centuries, New York, Oxford University Press 1992, p. 54.

43 V. Roudometof, "From Rum Millet to the Greek Nation: Enlightenment, Secularization, and National Identity in Ottoman Balkan Society, 1453-1821", in: Journal of Modern Greek Studies 16 (1/1998), p. 11-48.

44 Gale Stokes, "Church and Class in Early Balkan Nationalism", in: East European Quarterly 13 (3/1979), p. 259-270.

45 V. N. Makrides, "Why Are Orthodox Churches", p. 325-352.

46 V. Roudometof, Nationalism, Globalization and Orthodoxy: The Social Origins of Ethnic Conflict in the Balkans, Westport, CT, Greenwood Press 2001.
} 
Orthodox or belonging to the "Greek" [i.e. Orthodox] rite). Although the Rum millet was significant for tax collection and for grasping the Ottomans' mentality, the Orthodox community did not adhere to this structure solely as a result of an externally imposed definition. Rather, the Rum millet coalesced into a political-religious or confessional community predicated on the exalted role of the Orthodox Church, the status of higher education and the role of commerce. ${ }^{47}$ This model of confessional identity resembles that of several European states in the early modern era - and in some instances, like that of the Habsburg Serbs, it was formally applied to them even under a Christian (i.e. the Habsburg) emperor. This model remained the dominant one in Southeastern Europe up until the importation of nationalism into the region in the second half of the $18^{\text {th }}$ century.

The evolution of Church-State relations in the Orthodox part of Europe over the early modern and modern periods is characterized by two major features that have shaped the patterns of Church-State relations \& the development of political and religious cultures. The first major feature concerns the transport and transplantation of state Churches into the Orthodox part of Europe. These state Churches were largely modeled after the Lutheran state churches, which often relied upon the support of European monarchs. Perhaps the paradigmatic case concerns Russia. In the aftermath of the 1666-67 councils the Church hierarchy became closely aligned with the Empire. The State even instituted a separate department responsible for the management of the Church's extensive estates. In the early $18^{\text {th }}$ century, the instigation of Peter the Great's modernization program had important consequences for the Church. In 1721 the Spiritual Regulations abolished the Moscow Patriarchate and turned the Church into a department of the State, which was governed by a council of bishops, presided over by the Tsar's appointee, usually a retired general. ${ }^{48}$ The abolition of the Moscow Patriarchate by the State meant that for the next two centuries the Russian Church was completely aligned with Holy Russia, a powerful empire that collapsed only in 1917. The Moscow Patriarchate was revived only after the 1917 Bolshevik revolution.

The Lutheran model was also the inspiration behind the 1833 uncanonical proclamation of the Orthodox Church of Greece by the German Regency of King Otto, Greece's first king. The Church was formed as a branch of the State itself and that made its bishops accountable to political authority. These actions were the source of an extensive internal public dis-

\footnotetext{
47 P. M. Kitromilides, An Orthodox Commonwealth.

48 Dimitri Pospielovski, The Orthodox Church in the History of Russia, Crestwood, NY, St. Vladimir's Seminary Press 1998, p. 111-112.
} 
pute that was resolved only in 1850 when the Ecumenical Patriarchate issued a Tomos that recognized the Church of Greece's autocephaly. The formation of additional independent States with Orthodox majorities intensified this pattern and by the $20^{\text {th }}$ century, Bulgaria, Serbia and Romania had also their own state churches added to the list of autocephalous churches. ${ }^{49}$ In these States - especially the ones who came under communist control in the post1945 period - the Church was formally and informally forced to succumb to state control. ${ }^{50}$ In pre-World War II USSR as well as in post-World War II communist Albania the communist regimes carried out large scale persecution of the Orthodox churches, whereby large numbers of clergy and faithful were sent to concentration camps. ${ }^{51}$ But in post-World War II USSR as well as the majority of the communist East European states, communist rule did not lead to large scale persecution but rather in a somewhat symbiotic relationship. In contrast, the Orthodox Church of Cyprus - autocephalous in theory since its reconstitution in 1571 - developed a highly adversarial relationship with the island's post- 1878 British colonial authorities. ${ }^{52}$ Subsequently, the British declared the Church to be outside the control of public authority, effectively separating State from Church. But this is perhaps the only historical example in what is a growing historical pattern of Orthodox states instituting and/or controlling Orthodox churches.

The second major feature concerns the transference of the notion of nationalism into the population of the Orthodox part of Europe, whereby the peasantry of past centuries was effectively made into citizens of modern European nations. Before proceeding further, though, it is necessary to point out that these two features do not coincide. Having a state Church does not by any means suggest that this Church relates to a nation. In Russia, the Church served the Holy Russian Empire with the Tsar as its head. Moreover,

49 V. Roudometof, Nationalism, Globalization and Orthodoxy.

50 For regional overviews, see Stella Alexander, Church and State Relations in Yugoslavia Since 1945, Cambridge, Cambridge University Press 1979; Klaus Buchenau, "The Serbian Orthodox Church", in: Lucian Leustean (ed.), Eastern Christianity and the Cold War, 1945-91, London, Routledge 2009, p. 60-78; Ivan Zhelev Dimitrov, "Bulgarian Christianity”, in: Ken Parry (ed.), The Blackwell Companion to Eastern Christianity, Blackwell Publishing 2007, p. 42-72; Lucian N. Leustean, "For the Glory of the Romanians: Orthodoxy and Nationalism in Greater Romania, 1918-1945", in: Nationalities Papers 35 (4/2007), p. 717-742; idem, Orthodoxy and the Cold War: Religion and Political Power in Romania, 1947-65, London, Palgrave Macmillan 2009.

51 Nicholas Pano, "The Albanian Orthodox Church", in: Lucian Leustean (ed.), Eastern Christianity and the Cold War, 1945-91, London, Routledge 2009, p. 144-155; Tatiana A. Chumachenko, Church and State in Soviet Russia: Russian Orthodoxy from World War II to the Khrushchev Years, Armonk, NY, M. E. Sharpe 2002; Nathaniel Davis, A Long Walk to Church: A Contemporary History of Russian Orthodoxy, Boulder, CO, Westview Press 2003.

52 V. Roudometof, Globalization and Orthodox Christianity, chapter 6. 
the adoption of nationalism in the Orthodox part of Europe has been geographically uneven. That is, while modern nationalism spread throughout Southeastern Europe in the 19th century, in the Russian Empire no similar turn is observed..$^{53}$ The absence of Russian nationalism is in turn connected to the absence of a civil society ${ }^{54}$ whereby the people could negotiate their relationship vis-à-vis political authority. In imperial Russia, the cult of the Tsar as an absolute and divinely ordained monarch excluded such political considerations. Imperial Russia was superseded by Soviet communism. By creating a federal structure, the Soviets tacitly contributed to awareness of the territorial connections between people and nationality. ${ }^{55}$ But the Soviets did not foster the establishment of independent national churches, and even when it came to the Russian Orthodox Church, the Soviet regime's policies oscillated between tolerance and persecution. ${ }^{56}$ Practically, it was after 1991 that the post-Soviet nation-states (Russia, Moldova, Belarus, Ukraine and the Baltic states) could begin (or in some cases to begin anew) a belated process of constructing their sense of nationhood in the context of modern nation-states.

Unlike this historical pattern, the nation-states that were carved out of the European territories of the Ottoman Empire had already established assemblages of democratic governance during the 19th century. In these nation-states, the local intelligentsia used the appeal to the nation to transform traditional and communal ties into commitments framed in terms of broader civil spheres. The effective means by which this transformation was accomplished was the institution of separate national churches (Greece in 1833, Serbia in 1832, Romania in 1865 and the Bulgarian Exarchate in 1870). ${ }^{57}$ These new churches provided a medium through which the traditional ties of the confessional community of the Rum millet could be severed and new national ties could be forged. Although the institution of territo-

53 G. Hosking, "Can Russia Become”, p. 449-462; V. Roudometof, Nationalism, Globalization and Orthodoxy; David G. Rowley, "Imperial Versus National Discourse: The Case of Russia", in: Nations and Nationalism 6 (1/2011), p. 23-42.

54 Reinhard Bendix, Kings or People? Power and the Mandate to Rule, Berkeley, University of California Press 1978, p. 515-564.

55 Rogers Brubaker, Nationalism Reframed: Nationhood and the National Question in the New Europe, Cambridge, Cambridge University Press 1996.

56 D. Pospielovski, The Orthodox Church; T. A. Chumachenko, Church and State; N. Davis, A Long Walk.

57 V. Roudometof, "Invented Traditions, Symbolic Boundaries, and National Identity in Southeastern Europe: Greece and Serbia in Comparative-Historical Perspective 1830-1880", in: East European Quarterly 32 (4/1998), p. 429-468; P. M. Kitromilides, "The Legacy of the French Revolution: Orthodoxy and Nationalism”, in: M. Angold (ed.), The Cambridge History of Christianity. Vol. 5: Eastern Christianity, p. 229-249. 
rial autocephaly is part of the Orthodox tradition ${ }^{58}$, the construction of national churches in Southeastern Europe did not serve ecclesiastical purposes alone but, rather, provided the material and ideological infrastructure for the nationalization of masses. With the exception of Serbia, the process of establishing canonical autocephaly was protracted and full of disputes. The issue of ecclesiastical estates was prominent in Romania and in Greece and Bulgaria there were issues of canonicity. In these states, the new national churches provided for a critical ingredient of the modern understanding that shaped the relationship between Orthodoxy and nationality: a church-nation link that became essential for national identities. As a result, it became commonplace to refer to hyphenated versions of Orthodox (Serb-Orthodox, Greek-Orthodox, Bulgarian-Orthodox and so on). As Makrides ${ }^{59}$ sums it up: 'the old model 'Empire/Church/Emperor' was replaced by the modern model 'State/Church/Nation'."

This blending of modern national identities with Orthodoxy provides an essential component of the faith's adoption into the modern world. It also led to acute conflict, as the Balkan nation-states used the alignment of people in the Ottoman-held part of Europe with specific churches as proxy for their "nationality" ${ }^{60}$ Between the late 1860s and the 1912-1913 Balkan Wars, the systematic employment of church membership for political purposes became a thorny issue in Ottoman-held Macedonia. The Ecumenical Patriarchate condemned this tendency; ${ }^{61}$ however it was incapable of stopping the wave of nationalization that swept the Ottoman Empire. As national churches became autocephalous and as local nation-states annexed former regions of the Ottoman Empire, the Patriarchate was marginalized and following the 1923 Lausanne Treaty and the compulsory exchange of populations between Greece and Turkey, it lost the overwhelming majority of its former faithful.

After World War II, the majority of Balkan states came under communist control, but the new regimes mostly attempted to control the church's hierarchy - just as in post-World War II USSR. At times, even communist regimes employed strategically the creation of national churches in order to bolster the people's sense of national identity. For example, the national significance of the Bulgarian Orthodox Church was repeatedly recognized

58 V. N. Makrides, "Why Are Orthodox Churches", p. 325-352.

59 Ibidem, p. 332.

60 V. Roudometof, Collective Memory, National Identity and Ethnic Conflict: Greece, Bulgaria and the Macedonian Question, Westport, CT, Praeger 2002.

${ }^{61}$ Dimitrios Stamatopoulos, "The Bulgarian Schism Revisited”, in: Modern Greek Studies Yearbook 24-25 (2008/2009), p. 105-125; V. N. Makrides, "Why Are Orthodox Churches”, p. 325-352. 
under the communist rule. In 1962 the $200^{\text {th }}$ anniversary of the publication of Father's Paisii's 1762 history, which is considered the starting point for the Bulgarian national revival, was prominently celebrated; as well as the $100^{\text {th }}$ anniversary in 1970 of the creation of the Bulgarian Exarchate. ${ }^{62}$ In spite of the communist oversight, the maintenance of the church-nation link as part of the national mythology ensured the survival of the marginalized Orthodox churches in communist-held countries.

In the post-1989 era, the collapse of communist rule sparked a religious resurgence but also signaled further intertwining between nationalism and religion. ${ }^{63}$ According to Pew Research Center's latest survey results, in Orthodox countries religion is widely considered important for the nation's national identity. While that trend clearly registers the aforementioned historically constructed church-nation link, individuals do not necessarily practice their faith. In fact, low levels of Church attendance suggest that religion's significance is semiotic: Orthodoxy operates as a signifier of national membership. ${ }^{64}$ Religious worship and rituals are not necessarily manifestations of individual belief and religious practice does not necessarily reflect the depth of personal conviction or belief. ${ }^{65}$

In the post-1989 era, the intertwining between religion and nationalism persisted both in Southeastern Europe and the former USSR. But these two contexts vary widely. In Southeastern Europe, there were conflicts related to the collapse of former Yugoslavia, the rekindling of the Macedonian issue, and minority-majority issues; within nearly all of them there was some involvement of religion, either actual or rhetorical. But the church-nation link that was constructed in the $19^{\text {th }}$ century has remained vibrant ${ }^{66}$ and attempts to delink the two in the name of equality or EU directives or secularization policies face considerable reaction. In contrast, in the former USSR the cre-

62 James L. Hopkins, The Bulgarian Orthodox Church: A Socio-Historical Analysis of the Evolving Relationship Between Church, Nation and State in Bulgaria, Boulder, CO-New York, Columbia University Press 2009, p. 181-218.

63 Pipa Norris, Ronald Inglehart, Sacred and Secular: Religion and Politics Worldwide, New York, Cambridge University Press 2004; Alexander Agadjanian, V. Roudometof, "Eastern Orthodoxy in a Global Age: Preliminary Considerations", in: V. Roudometof, A. Agadjanian, J. Pankhurst (eds.), Eastern Orthodoxy in a Global Age: Tradition Meets the 21st Century, Walnut Creek, CA, Alta Mira Press 2005, p. 1-26; Pew Research Center, Religious Belief and National Belonging in Central and Eastern Europe, http://www.pewforum.org/2017/05/10/religious-belief-and-national-belonging-in-central-and-eastern-europe/, viewed on May 10, 2017.

64 A. Agadjanian, V. Roudometof, "Eastern Orthodoxy", p. 1-26.

65 Inna Naletova, "European Secularity and Religious Modernity in Russia and and Eastern Europe: Focus on Orthodox Christianity", in: Robert W Hefner, John Hutchinson, Sara Mels, Christiane Timmerman (eds.), Religions in Movement: The Local and the Global Contemporary Faith Traditions, New York, Routledge 2013, p. 57-78.

66 Pew Research Center, Religious Belief and National Belonging in Central and Eastern Europe. 
ation of nation-states that could operate without the constraints of communist oversight led to the reconstitution or creation of new national churches, similar in many respects to those created in the $19^{\text {th }}$ century Balkans. The church-nation link was openly asserted and the involvement of religion into national politics and regional disputes duplicated the pattern of the regional antagonisms that plagued $19^{\text {th }}$ century Balkans. In the post-Soviet republics, close to thirty million Russians were left outside the Russian Federation; and the creation of new independent states in the former Soviet space led to the application of the age-old strategy of ecclesiastical autocephaly as a means of bolstering these states' newfound independence. ${ }^{67}$ In these instances several ecclesiastical disputes emerged. These involve the notion of Russian Orthodoxy as a transnational religion that operates beyond the borders of the Russian Federation. For the Russian Orthodox Church, the Russians living outside the borders of the Russian Federation are part of a broader "Russian world" with the Church as its custodian. The most important cases are those of Estonia, Ukraine and Moldova. These cases have also involved the Ecumenical Patriarchate as well as the Romanian Orthodox Church. ${ }^{68}$

\section{Conclusions}

In this discussion, I have sketched an alternative socio-historical interpretation that shows how one can employ the notion of globalization in order to incorporate Orthodox Christianity into global history and produce an account that does not view Orthodox Christianity as a backward-looking faith. In this account, I have used the notion of world-historical globalization in order to explain how the differential adoption of Christianity in the eastern and western part of Europe increased the religion's propensity for regional adaptations that contributed heavily to cross-regional or geopolitical antagonisms and rivalries. These rivalries culminated with the 1204 collapse of the eastern Roman Empire; but the empire's demise only served as the geopolitical context which in turn strengthened the ability of religious hierarchies to operate independently of state authority, hence leading to the post-1204 crystallization of Orthodox Christianity and Roman Catholicism as distinct and often competing branches of Christianity. In terms of Church-State relations, it is clear that the pre-1204 empire operated in accordance to the model of complementarity between public authority and religious hierarchy. In the post-1453 era though, the Ottoman and Russian empires developed their own models, which clearly diverge from the blueprint of symphonia. In

\footnotetext{
67 V. Roudometof, Globalization and Orthodox Christianity, p. 79-101.

68 Daniel P. Payne, "Nationalism and the Local Church: The Source of Ecclesiastical Conflict in the Orthodox Commonwealth", in: Nationalities Papers 35 (5/2007), p. 831-852.
} 
the Ottoman Empire, submission to a Muslim overlord was justified on the basis of the Christians' past sins. In the Russian empire, the institution of a divinely ordained monarchy eventually turned the Russian Church into a department fully controlled by the State.

Moreover, the independence of religious authority was seriously curtailed as part of state-sponsored programs of modernization. Modeled after the Lutheran state churches, the institution of State Churches became transplanted into the Orthodox part of Europe. In addition to this change, a major shift took place with the adoption of nationalism in the Orthodox part of Europe: the institution of national churches connected or reframed the people's relationship to religious authority, whereby the Orthodox churches received newfound support as part of the process of nation-building. That in turn constructed a church-nation link for modern Orthodox nations, which persisted even when, in the course of the $20^{\text {th }}$ century, many of the Orthodox countries were under communist control. I have stressed the extent to which this process originated in Southeastern Europe - and the fact that, for the post-Soviet space, this process of constructing national churches was openly asserted only after the post-1989 collapse of communism and the reconfiguration of the geopolitical map of Eastern Europe. It might be relevant to remind readers in this context that the historical intertwining of faith and nation and the semiotic significance of religion are not necessarily patterns unique to the Orthodox part of Europe. One can easily find evidence of the same processes in the non-Orthodox countries of Europe - hence, it is misleading and inaccurate to view these features as elements of a non-existent Orthodox exceptionalism vis-à-vis Western Europe.

Lastly, I should briefly add that the above discussion does not address the issue of religious transnationalism, which is highly relevant for understanding Orthodoxy's present condition as well as future trends. From the 1870s forward, there have been extensive waves of Orthodox immigration out of Eastern Europe and toward North America (during the 1870-1920 era of mass European immigration) and, over the post-1989 era, toward Western Europe ${ }^{69}$. International migration has led to the creation of transnational communities who use ecclesiastical institutions as part of their resettlement and readjustment processes. Different groups of immigrants have organized ecclesiastical hierarchies in their host countries. Most of the Orthodox national churches operate as mother churches that have set up diasporic churches to minister their co-nationals.

69 V. Roudometof, "Orthodox Christianity as a transnational religion: theoretical, historical and comparative considerations", in: Religion, State and Society 43 (3/2015), p. 211-227. 